\title{
KAJIAN PENERAPAN PERMAINAN BOWLING BERBAHAN BEKAS PADA KEMAMPUAN BERHITUNG PERMULAAN ANAK
}

\author{
Fiska Fara, Rosita Wondal, Nurhamsa Mahmud \\ PG PAUD FKIP UNIVERSITAS KHAIRUN TERNATE \\ Jl, Bandara Sultan Babullah Kota Ternate Utara,Kode Pos 53 Ternate 97728 \\ Email: fiskafara3@gmail.com
}

\begin{abstract}
Abstrak:
Dunia anak adalah dunia bermain, anak belajar melalui bermain. Salah satu permainan yang dapat mengajarkan anak dalam berhitung adalah permainan boling .Kemampuan berhitung pada anak usia dini perlu di asah sejak dini. Berhitung, pad anak usia dini merupakan bagian dari keenam aspek perkembangan yanitu aspek kognitif. Anak yang diasah perkembangan kognitifnya sejak dini akan membantu anak menjadi pribadi yang memiliki intelektual yang baik. Tujuan dari penelitian ini adalah untuk mengkaji tentang penerapan permainan boling berbahan bekas pada kemampuan berhitung permulaan. Melalui metode kajian penilitian literatur Dari hasil penelitian dapat di simpulkan bahwa permainana bowling berbahan bekas dapat meningkatkan kemampuan berhitung permulaan anak.
\end{abstract}

Kata kunci: Permainan Bowling , Berhitung Permulaan

\begin{abstract}
:
Children world is the world of play, children learn through playing. One game that can teach children to count is bowling. The ability of numeracyneeds to be sharpened. Counting in early childhood is part of the six aspects of development that are cognitive aspects. Children who have good cognitive developmentmust be taught early so that they will have good intellectuals also. The study aim is to examine the application of bowling games with used material on children numeracy ability through literature research studies. The results showed that bowling games with used material can improve children numeracy skill.
\end{abstract}

Key words: Bowling games, early math

\section{A. Pendahuluan}

Masa anak-anak merupakan salah satu masa dalam rentang kehidupan manusia yang pasti dilalui oleh semua manusia di dunia ini. Pada masa inilah terjadi banyak sekali proses penanaman nilai kehidupan yang pertama kali. Pada masa ini pulah, selalu bertumpu harapan dari para orangtua yang selalu menginginkan anakanaknya nanti dapat menjadi seorang yang berguna dan dapat sukses di masa yang mendatang. Maka tidak heran jika banyak orang tua yang mulai berlomba-lomba memasukan anaknya ke sekolah favorit, dengan harapan dapat memberikan pendidikan yang lebih berkualitas, sehinga anak dapat menjadi anak yang pintar, cerdas dan memiliki kepribadian yang baik. Bukan suatu hal yang mengherankan jika para orangtua menginginkan hal-hal tersebut, mengingat anak-anak adalah orangorang yang akan meneruskan tongka estafet dari para orangtua. Anak-anak adalah generasi penerus bangsa. Di tangan anak-anak terapat masa depan bangsa, anak-anak adalah warisan yang paling berharga yang harus di jaga baik-baik. Oleh karna itu anak perlu di bimbing agar mampu memahami berbagai hal tentang dunia dan isinya. PAUD merupakan salah satu media dan wadah untuk membimbing anak dalam mengenali dunianya. Menurut Undang-undang nomor 20 tahun 2003 (dalam permendiknas no 58 tahun 2009) tentang sistem pendidikan nasional bahwa pendidikan anak usia dini adalah anak yang berada pada usia 0-6 tahun yang merupakan masa di mana anak mulai mengalami perumbuhan dan perkembangan. Pendidikan Anak Usia Dini adalah 
suatu upaya pembinaan yang di tunjukan melalui pemberian rangsangan pendidikan untuk membantu pertumbuhan dan perkembangan jasmani dan rohani agar anak memiliki kesiapan dalam memasuki pendidikan lebih lanjut. Penyelengaraan Pendidikan Anak Usia Dini (PAUD) dapat di lakukan dalam bentuk formal, nonformal dan informal. Penyelengaraan Pendidikan Anak Usia Dini dalam bentuk formal adalah Taman Kanak-Kanak (TK) atau Raudatul Athfal (RA) atau lembaga sejenis. Penyelengaraan PAUD dalam bentuk nonformal di selengarakan oleh masyarakat atas dasar kebutuhan dari masiyarakat itu sendiri, khususnya di tunjukan kepada anakanak yang dengan keterbatasannya tidak terlayani di jalur formal seperti TK atau RA. Sedangkan pendidikan di jalur informal yaitu pendidikan yang di lakukan oleh keluwarga atau lingkungan anak itu sendiri.

Pendidikan di taman kanak-kanak bertujuan untuk membantu anak dalam mengembangkan berbagai potensi baik psikis dan fisik yang meliputi moral dan nilai agama, fisik motorik, kognitif, sosial emosional, bahasa dan seni untuk siap memasuki pendidikan selanjutnya. Masa usia tanam kanak-kanak merupakan masa emas, di mana perkembangan fisik motorik, kognitif, sosial emosional, bahasa dan seni anak berkembang dengan sangat cepat. Untuk mencapai perkembangan anak tersebut di lakukan dalam kegiatan pembelajaran di taman kanak-kanak yang lebih di kenal dengan kegiatn bermain. Dunia anak adalah dinia bermain, anak-anak selalu melakukan kegiatan pembelajaran melalui bermain. Anak belajar melalui bermain dalam suasana yang menyenangkan akan membuat belajar anak menjadi lebih baik, serta dalam kegiatan belajarnya anak dapat menggunakan seluru alat inderanya. Salah satu aspek yang harus di kembangkan pada anak usia dini adalah aspek kognitif. Usaha untuk menggali kemampuan kognitif yang di miliki oleh anak dapat di lakukan dengan berbagai cara termasuk melalui kegiatan pengembangan kemampuan berhitung. Kemampuan berhitung adalah kemampuan untuk menggunakan penalaran logika dan angka-angka. Kemampuan berhitung adalah kemampuan yang di miliki oleh setiap anak dalam hal matematika seperti pengenalan konsep bilangan, lambang bilangan, warna, bentuk, ukuran, ruang, posisi dan dapat membentuk sikap logis, kritis, cermat dan kreatif pada diri anak. Dalam aspek pengembangan kognitif kemampuan yang di harapkan anak usia 5 sampai 6 tahun sudah dapat menyebutkan urutan bilangan dari 1 sampai 100. Namun pada kenyataannya anak belum mampu menyebutkan urutan bilangan, memahami ketika di minta menunjukan lambang bilangan yang di sebutkan terkadang anak masih sering keliru dalam menuliskan lambang bilangan. Hal ini menunjukan bahwa dalam pembelajaran anak belum di stimulasi secara optimal. Ini terlihat dalam pembelajaran anak menyebutkan urutan bilangan, anak-anak belajar tentang bilangan hanya dengan cara bersama-sama menyebutkan urutan bilangan setelah di minta guru. Selain itu juga karena kurangnya variasi media yang di gunakan dalam kegiatan pembelajaran. Pembelajaran yang di lakukan oleh guru kurang menarik perhatian anak dalam kegiatan belajar. Media yang digunakan guru hanya berfokus pada media yang sudah ada, padahal kenyataan di lapangan begitu banyak media yang bisa di gunakan dan di manfaatkan untuk meningkatkan kemampuan berhitung awal pada anak usia dini.

Berhitung merupakan bagian dari matematika, diperlukan untuk menumbuh kembangkan keterampilan berhitung yang sangat diperlukan dalam kehidupan seharihari, terutama konsep bilangan yang merupakan juga dasar bagi pengembangan kemampuan matematika maupun kesiapan untuk mengikuti pendidikan dasar. Pembelajaran permainan berhitung pemula di taman kanak-kanak. Kemampuan berhitung awal adalah kemampuan yang dimiliki setiap anak untuk mengembangkan kemampuannya, karakteristik perkembangannya dimulai dari lingkungan yang 
terdekat dengan dirinya, sejalan dengan perkembangan kemampuannya anak dapat meningkat ke tahap pengertian mengenai jumlah, yang berhubungan dengan penjumlahan dan pengurangan. Susanto dalam Khadijah (2016: 143). Depdiknas (2000:2) menjelaskan tujuan dari pembelajaran berhitung di taman kanak-kanak, yaitu secara umum berhitung permulaan di taman kanak-kanak adalah untuk mengetahui dasar-dasar pembelajaran berhitung sehingga pada saatnya nanti anak akan lebih siap mengikuti pembelajaran berhitung pada jenjang selanjutnya yang lebih kompleks. Sedangkan secara khusus dapat berpikir logis dan sistematis sejak dini melalui pengamatan terhadap benda-benda konkrit gambar-gambar atau angka-angka yang terdapat di sekitar, anak dapat menyesuaikan dan melibatkan diri dalam kehidupan bermasyarakat yang dalam kesehariannya memerlukan kemampuan berhitung, ketelitian, konsentrasi, abstraksi dan daya apresiasi yang lebih tinggi, memiliki pemahaman konsep ruang dan waktu serta dapat memperkirakan kemungkinan urutan sesuai peristiwa yang terjadi di sekitarnya, dan memiliki kreativitas dan imajinasi dalam menciptakan sesuatu secara spontan. Terkait dengan masalah tersebut, perlu adanya perbaikan dalam kegiatan pembelajaran yang diharapkan mampu mengoptimalkan kemampuan berhitung permulaan pada anak sejak usia dini. Oleh sebab itu penulis ingin melakukan suatu kegiatan tentang permainan bowling berbahan bekas sebagai media untuk pengembangan berhitung permulaan pada anak usia dini.

Metode yang digunakan dalam penelitian ini dengan pendekatan studi literatur (library reseach). Menurut Zeed Mestika (2014) menyatakan bahwa metode penelitian dengan pendekatan study literatur merupakan penelitian yang serangkaian kegiatannya dengan metode pengumpulan data pustaka, buku-buku, serta tulisan yang terkait dengan judul penelitian ini.

\section{B. Pembahasan}

\section{1. kemampua berhitung}

Putri (2014 : 3) berhitung merupakan suatu kegiatan melakukan, mengerjakan hitungan seperti menjumlah, mengurangi dan memanipulasi bilangan-bilangan dan lambang-lambang matematika. Berhitung juga merupakan dasar dari beberapa ilmu yang di pakai dalam setiap kehidupan manusia. Menurut Susanto dalam Himmatul (2017: 3). Mengingat begitu pentingnya kemampuan berhitung bagi manusia, maka kemampuan berhitung ini perlu di ajarkan sejak dini, dengan berbagai meda dan metode yang tepat sehingga tidak dapat merusak pola perkembangan anak. Pembelajaran matematka pada anak usia dini haruslah melalui cara yang sederhana dan tepat serta di lakukan secara konsisten dan kontinu dalam suasana yang kondusif dan menyenangkan, maka otak anak akan terlati untuk terus berkembang sehingga anak dapat menguasai, dan bahkan menyenangi matematika tersebut.

Berhitung juga memiliki manfaat yang sangat besar (Montolalu, 2005:1.19), adapun manfaat berhitung awal adalah sebagai berikut:

a. Mengoptimalkan fungsi otak. Pembelajaran berhitung awal terbukti sangat berguna dalam mengoptimalkan fungsi-fungsi otak (otak kanan khususnya) yang meliputi daya analisa, ingatan, logika, visi, kemandirian, ketekunan, penemuan dan penerapan. Dengan memahami disiplin dasar eksakta ini, manusia diharapkan dapat menguasai dan menggunakan secara optimal seluruh potensi dan kreativitas yang ada dalam menyerap ilmu-ilmu yang tentunya akan bermanfaat dalam kehidupannya sehari-hari. 
b. Melatih daya imajinasi dan kreativitas, logika, sistematika berfikir, daya konsentrasi dan daya ingat. Ini dicapai dengan melatih otak kiri dan kanan menjadi lebih aktif melalui pembelajaran berhitung.

c. Meningkatkan kecepatan, ketepatan dan ketelitian dalam berfikir.

d. Menjadi lebih sensitif terhadap aransemen spatial akibat pengaruh dari membayangkan sempoa dalam otak kita.

e. Untuk anak-anak yang suka lalai menghafal rumus perkalian, mental aritmatika sangat membantu.

f. Menumbuhkan rasa percaya diri dan sikap mental positif, terutama dalam menghadapi soal-soal matematika atau berhitung.

Berhitung permulaan merupakan salah satu kemampuan yang sangat penting bagi anak yang perlu dikembangkan dalam rangka membekali anak dikehidupannya di masa depan. Berhitung merupakan dasar dari beberapa ilmu yang dipakai dalam setiap kehidupan manusia. Mengingat begitu pentingnya kemampuan berhitung bagi manusia, maka kemampuan berhitung ini perlu diajarkan sejak dini, dengan berbagai media dan metode yang tepat sehingga tidak dapat merusak pola perkembangan anak. Pembelajaran matematika pada anak sudia dini haruslah melalui cara yang sederhana dan tepat serta dilakukan secara konsisten dan kontinu dalam suasana yang kondusif dan menyenangkan, maka otak anak akan terlatih untuk terus berkembang sehingga anak dapat menguasai, dan bahkan menyenangi matematika tersebut. Susanto (2011: 65). Kemampuan berhitung permulaan adalah kemampuan yang dimiliki setiap anak untuk mengembangkan kemampuannya, karakteristik perkembangannya dimulai dari lingkungan yang terdekat dengan dirinya, sejalan dengan perkembangan kemampuannya anak dapat meningkat ke tahap pengertian mengenai jumlah, yang berhubungan dengan penjumlahan dan pengurangan. Khadijah (2016: 143). Kegiatan berhitung untuk anak usia dini disebut juga sebagai kegiatan menyebutkan urutan bilangan atau membilang buta. Anak menyebutkan urutan bilangan tanpa menghubungkan dengan benda-benda konkrit. Pada usia 4 tahun mereka dapat menyebutkan urutan bilangan sampai sepuluh. Sedangkan usia 5 sampai 6 tahun dapat menyebutkan bilangan sampai seratus. Sriningsih (2008: 63). Berhitung permulaan merupakan salah satu kemampuan yang sangat penting bagi anak yang perlu di kembangkan dalam rangka membekali anak dikehidupannya di masa depan.

\section{Permainan Bowling}

Kata bermain mungkin terdengar kurang serius, hanya untuk mengisi waktu luang saja, walaupun tidak dilakukan oleh anak. Padahal bagi anak-anak kegiatan bermain merupakan kegiatan yang sangat mutlak dibutuhkan, sebab dunia anak adalah dunia bermain, bagaimana mereka memahami dunianya adalah melalui bermain. Menurut pendapat Sudono (2003: 65), bermain adalah pekerjaan masa kanak-kanak dan cermin pertumbuhan anak dan bermain merupakan kegiatan yang memberikan kepuasan bagi anak itu sendiri. Melalui bermain anak memperoleh pembatasan dan memahami kehidupan. Para ahli psikologi anak menekankan pentingnya bermain bagi anak. Bagi anak-anak, bermain merupakan kegiatan yang alami dan sangat berarti. Dengan bermain anak mendapat kesempatan untuk mengadakan hubungan yang erat dengan lingkungan. Bermain adalah suatu kegiatan yang serius, tetapi mengasyikkan mempunyai arti dalam kehidupan anak yaitu mampu membawa anak ke perubahan yang baik dalam berbagai aspek kehidupannya (Semiawan, 2008 : 20). Hurlock (2005: 320) 
mengartikan bermain adalah setiap kegiatan yang dilakukan untuk kesenangan yang ditimbulkannya, tanpa mempertimbangkan hasil. Bermain dilakukan secara sukarela dan tidak ada paksaan atau tekanan dari luar atau kewajiban. Bermain merupakan keseluruhan aktivitas yang dilakukan oleh seseorang individu yang sifatnya menyenangkan, menggembirakan, dan menimbulkan kenikmatan yang berfungsi untuk membantu individu mencapai perkembangan yang utuh, baik fisik, intelektual, sosial, moral dan emosional. Bermain merupakan kegiatan santai, menyenangkan tanpa tuntutan (beban) bagi anak. Bermain juga merupakan kebutuhan yang esensial bagi anak. Melalui bermain anak dapat memuaskan tuntutan dan kebutuhan perkembangan demensi motorik, kognitif, kreatifitas, emosi, sosial, nilai, bahasa dan sikap hidup.

Permainan bowling ialah suatu jenis olaragah atau permainan yang di mainkan dengan menggelindingkan atau melempar bola menggunakan tangan. Bola bowling akan digelinding atau dilempar kepin yang berjumlah sepuluh buah yang telah disusun menjadi bentuk segi tigga jika di lihat dari atas. Jika semua pin di jatuhkan dalam sekali gelinding maka itu d sebut strike. Jika pin tidak di jatuhkan sekaligus maka di berikan satu kesempatan lagi untuk menjatuhkan pin yang tersisa Strickland dalam Hikmah (2017). Menurut Mikanda Rahmani (2014:165) , bahwa bowling termasuk salah satu jenis cabang olahraga permainan yang dilakukan dengan menggelindingkan bola bowling menuju lintasan lurus untuk menjatuhkan pin sebanyak mungkin. Berdasarkan pendapat tersebut dapat disimpulkan bahwa bowling merupakan olahraga permainan yang dilakukan dengan menggelindingkan bola dengan tujuan menjatuhkan pin sebanyak mungkin dalam jarak tertentu. Selanjutnya Purnomo (2013: 96-97) menyatakan dengan melakukan permainan ini, ada 6 kecerdasan yang dapat dikembangkan: kecerdasan spasial, dan kinestetik-jasmani, ketika anak mencari strategi, memperkirakan kekuatan yang digunakan, melempar bola, dan berusaha menjatuhkan kaleng sebanyak mungkin. Kecerdasan logis-matematis, anak dapat menghitung kaleng-kaleng/botol-botol yang telah jatuh. Kecerdasan intrapribadi dan antarpribadi, ketika bekerja sama untuk membereskan kembali kalengkaleng/botol-botol yang telah jatuh dan Kecerdasan verbal/linguistik dapat berkembang ketika anak berdiskusi mengenai permainan ini.

Cara bermain dalam permainan ini tentu di sesuaikan dengan tujuan pembelajaran yakni untuk mengembangkan kemampuan berhitung permulaan anak. Ada pun langkah-langkah permainan boling berbaha bekas yang dibuat menjadi lebih sederhana sebaga berikut : Pin di susun membentuk segi tiga anak di minta secara bergiliran untuk maju mengambil posisi berdiri 5 meter jaraknya dari pin, posisi anak untuk melakukan permainan boling berbahan bekas di sesuaikan dengan kondisi anak, dapat di lakukan dengan posisi berdiri, membungkuk atau duduk di lantai. Selanjutnya untuk mendorong bola, anak dapat mengunakan satu tangan atau dua tangan sesuai dengan kemampuan tangan yang bisa untuk beraktivitas secara maksimal. Anak di minta menggelndingkan bola ke arah pin, lalu di hitung jumlah pin yang jatuh, setelah itu di hitung juga sisa pin yang tidak terjatuh. Anak yang dapat menjatuhkan semua pin dalam satu kali gelinding makah dia lah sebagai pemenag sedangkan anak yang tidak dapat menjatuh kan semua pin di berikan kesempatan sekali lagi untuk menjatuhkan pin yang masih tersisa. Penulis menerapkan permainan bowling untuk meningkatkan kemampuan berhitung permulaan dan permainan ini dapat di modifikasi menjadi permainan sederhana dengan menggunaka bahan-bahan bekas. Permainan ini di sesuaikan dengan tujuan serta kemampun dan kondisi anak. Penyesuayan dalam 
permainan bowling berbahan bekas ini terletak pada peralatan yang di gunakan, jarak anak dengan pin dan cara bermainnya. Peralatan yang di buat dari bahan bekas baik pin maupun bola, dalam hal ini anak usia dini yang tidak dapat mengangkat atau memegang barang yang terlalu berat, sehingga di buat bola dari kain-kain bekas dan pin dari botol plastik yang lebih ringan sehingga tidak membuat anak mudah lelah dan kesulitan dalam melakukan permainan.

kelebihan permainan bowling Isnaini Sholihah (2014:33) adalah

1. Anak terlibat aktif dalam pembelajaran.

2. Permainan bowling berbahan bekas dapat mengembangkan tiga aspek yaitu aspek kognitif, afektif dan psikomotorik dapat tercapai.

3. Permainan dikemas secara menyenangkan sehingga anak akan ikut serta dengan rasa sukarela dan gembira.

4. Permainan bowling berbahan bekas akan mendorong kemampuan menalar atau berfikir anak sehingga anak belajar untuk memecahkan masalah.

kekurangan pemainan bowling yaitu: Permainan bowling berbahan bekas hanya terbatas pada materi matematika penjumlahan dan pengurangan saja

Efektivitas merupakan sesuatu yang memberikan pengaruh tau membawa hasil yang di timbulkan dari suatu tindakan. Efektivitas adalah faktor yang sangat penting dalam pelajaran karena menentukan tingkat keberhasilan suatu metode maupun media pembelajaran yang di gunakan. Kamus Besar Bahasa Indonesia (2008:375 ), menjelaskan bahwa efektif berati ada efeknya (akibat, pengaruh atau kesan ). Efektivitas yang di maksud adalah tujuan yang akan di capai melalui permainan bowling berbahan bekas terhadap kemampuan berhitung permulaan anak, permainan bowling berbahan bekas adalah permainan yang di buat dari bahan-bahan bekas untuk pembelajaran berhitung permulaan. Berdasarkan uraian tersebut, efektivitas permainan bowling berbahan bekas ini dapat membawa hasil atau memberi efek baik terhadap kemampuan berhitung permulan. Efektivitas permainan boling berbahan bekas ini dapat di nilai berdasarkan kegiatan anak dalam melakukan permainan, yakni dalam kegiatan menghitung jumlah pin semulah yang disusun, kemudian anak menggelindingkan bola kearah pin sehingga mengenai pin, kemudian pin yang terkena bola akan jatuh. Anak menghitung pin yang jatuh tersebut dan pin yang tidak terjatuh. Melalui kegiatan menghitung secara kongkrit tersebut maka permainan ini akan membawa hasil yang baik dalam pembelajaran berhitung permulaan. Permainan bowling berbahan bekas ini juga mampu untuk menarik minat maupun motivasi anak dalam belajar, terutama dalam belajar berhitung permulaan. Adanya permainan bowling berbahan bekas dapat menimbulkan keinginan anak untuk belajar karena pembelajaran di lakukan sambil bermain, sehingga anak tidak akan merasa bosan. Selain itu, anak juga merasa senang jika dapat menjatuhkan pin yang di susun sehingga anak ingin melakukan permainan secara berulang-ulang. Permainan ini juga baik untuk melatih motorik anak, baik motorik halus maupun motorik kasar. Pada aktivitas memegang bola, motorik halus anak dilatih dalam gerakan jari tangan yang menggenggam bola. Selanjutnya, pada kegiatan mendorong atau menggelindingkan bola ke arah pin, kegiatan tersebut melatih motorik kasar pada anak. Gerak motorik kasar ini membutuhkan koordinasi sebagian besar bagian tubuh anak. Oleh karena itu, biasanya memerlukan tenaga karena dilakukan oleh otot-otot yang lebih besar, sehingga permainan ini juga dapat meningkatkan kebugaran serta melatih koordinasi tubuh anak. 


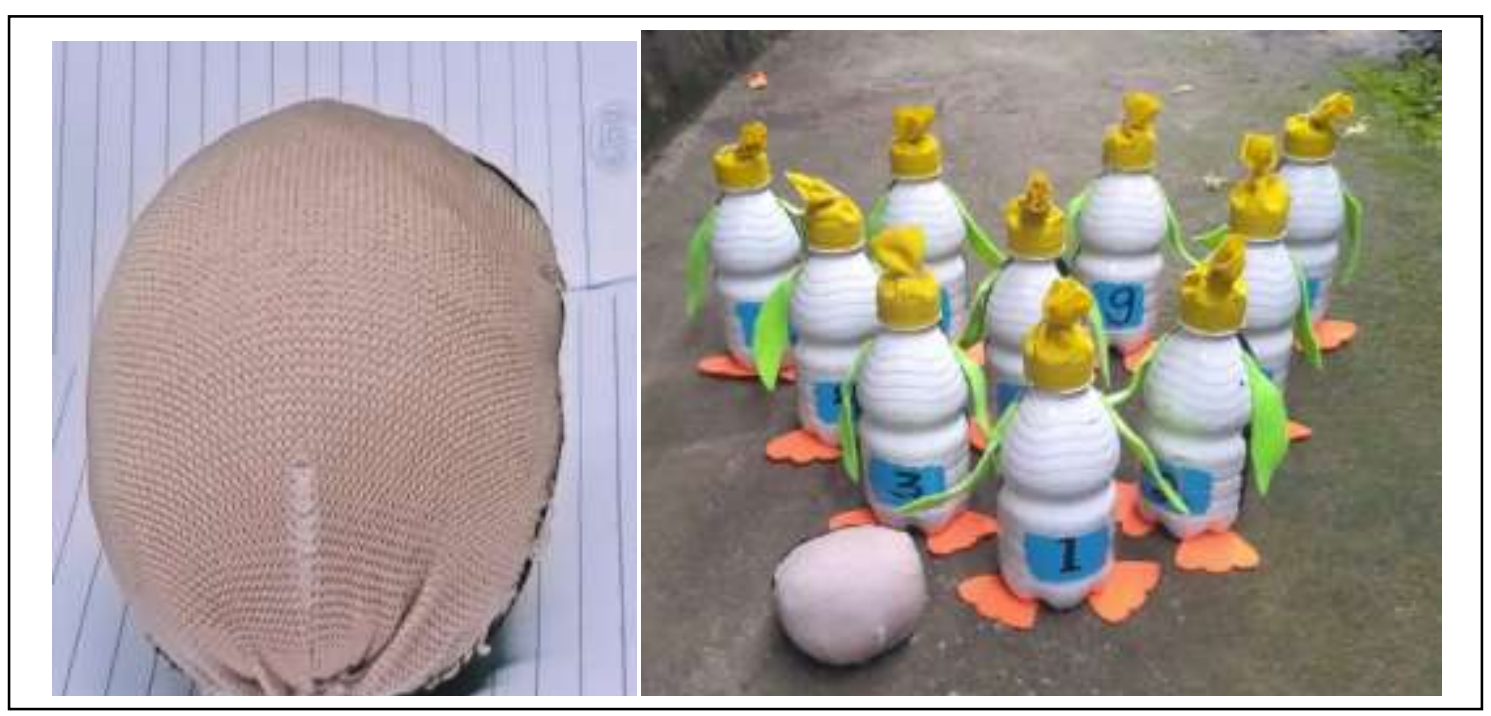

Gambar 1. Bowling Berbahan Bekas

Banyak penelitian yang telah melakukan penelitian tentang mengembangkan kemampuan berhitung pada anak usia dini. Menurut hasil penelitian yang dilakukan oleh Rosa Imani Khan dan Ninik Yuliani (2016) dengan judul penelitian, Meningkatkan Kemampuan Berhitung Anak Usia Dini Melalui Permainan Bowling Kaleng. Subjek penelitian ini terdiri dari 30 anak di kelompok B TK Dharma Wanita Gogorante, Kediri. Metode yang digunakan adalah penelitian tindakan kelas dalam 2 putaran. Setiap putaran terdiri dari empat fase; perencanaan, pelaksanaan, observasi dan refleksi. Tujuan dari penelitian ini adalah untuk meningkatkan kemampuan berhitung anak usia dini melalui permainan Bowling Kaleng. Hasil penelitian menunjukan bahwa pembelajaran melalui permainan Bowling kaleng telah berhasil meningkatkan kemampuan berhitung anak. Selanjutnya penelitian yang dilakukan oleh Nia Fatmawati (2014) dengan judul penelitian peningkatan kemampuan berhitung melalui pendekatan realistic mathematic education. Hasil penelitian menunjukkan bahwa pembelajaran dengan pendekatan Realistic Mathematic Education dapat meningkatkan kemampuan berhitung siswa. Dimana siswa pada pra-tindakan adalah 50\%, siklus satu 75\%, dan siklus dua mencapai $81,25 \%$. Metode penelitian ini menggunakan metode penelitian tindakan yang dikembangkan oleh Kemmis dan Taggart. Tindakan dilakukan dalam dua siklus. Masing-masing siklus terdiri dari tahapan perencanaan, tindakan, pengamatan, dan refleksi. Teknik pengumpulan data adalah observasi, wawancara, dan dokumentasi. Analisis data menggunakan statistik deskriptif dan model interaktif Miles dan Huberman, meliputi: data reduction, display, and conclusion drawing or verification. Tujuan dari penelitian ini yaitu untuk meningkatkan kemampuan berhitung siswa melalui pendekatan Realistic Mathematic Education.

Hal yang sama di lakukan oleh Qoyumil Hikmah, Misno A. Lathif, Khutobah (2016) dengan judul peniltian Peningkatan Kemampuan Berhitung Pada Anak Kelompok B Melalui Permainan Kartu Angka di TK Dharma Indria I Kecamatan Patrang Kabupaten Jember. Subjek penelitian seluruh anak kelompok B TK Dharma Indria I berjumlah 30 anak, yang terdiri atas 15 anak laki-laki dan 15 anak 
perempuan. Jenis penelitian ini adalah penelitian tindakan kelas. Teknis analisisnya deskriptif kualitatif dan kuantitatif. Rancangan penelitian ini terdiri atas empat tahap yaitu perencanaan, pengamatan, tindakan, dan refleksi. Metode pengumpulan datanya adalah metode observasi, wawancara, tes dan dokumentasi. Tujuan dari penelitian ini adalah untuk meningkatkan kemampuan berhitung anak .Hasil penelitian menunjukan bahwa permainan kartu angka dapat meningkatkan kemampuan berhitung pada anak . Sri Handayani, (2012) juga melakukan penelitian dengan judul Peningkatan Kemampuan Berhitung Anak Melalui Permainan Ular Tangga Di Taman Kanak-Kanak Aisyiyah Simpang Iv Agam. Subjek penelitian adalah anak-anak di kelas B1 dengan jumlah murid 20 orang. 11 orang anak laki-laki dan 9 orang anak perempuan. Tujuan penelitian ini untuk meningkatkan kemampuan berhitung anak melalui permainan ular tangga. Jenis penelitian ini adalah penelitian tindakan kelas. Menggunakan metode praktek langsung. Penelitian ini di lakukan dalam dua siklus. Hasil penelitian ini telah menunjukan adanya peningkatan kemampuan berhitung pada siklus ke II. Di simpulkan bahwa dengan menggunakan permainan ular tangga dapat meningkatkan kemampuan berhitung anak di Taman Kanak-kanak Aisyiyah Simpang IV Lubuk Basung.

Nova Oktriyani ( 2017) juga melakukan penelitian dengan judul peningkatan kemampuan berhitung anak usia dini melalui permainan lingkaran angka di taman kanak-kanak Qatrinnada Kecamatan Koto Tangah Padang. Hasil penelitian setiap siklus menunjukkan adanya peningkatan berhitung anak melalui permainan lingkaran angka, namun pada siklus I belum mencapai kriteria ketuntasan minimal, sehingga dilanjutkan ke siklus II. Pada siklus II, meningkat mencapai di atas kriteria ketuntasan minimal. Hal ini menunjukkan bahwa perkembangan kemampuan berhitung anak didik mengalami peningkatan melalui permainan lingkaran angka. Jadi, dapat disimpulkan bahwa melalui permainan lingkaran angka dapat meningkatkan kemampuan berhitung anak usia dini. Metode penelitian ini menggunakan metode penelitian tindakan kelas (PTK) dengan subjek penelitian kelompok B4 yang berjumlah 10 orang. Penelitian ini dilakukan dalam dua siklus. SiklusI dilaksanakan tiga kali pertemuan dan siklus II tiga kali pertemuan yang dilakukan berdasarkan tahap pelaksanaannya yaitu perencanaan, pelaksanaan tindakan, pengamatan dan refleksi. Tujuan penelitian ini adalah untuk meningkatkan kemampuan berhitung anak didik di taman kanakkanak Qatrinnada Kecamatan Koto Tangah Kota Padang melalui permainan lingkaran angka. Selanjutya Penelitian yang sama di lakukan oleh Titin Nirawati, Rivda Yetti (2019) dengan judul Peningkatan Kemampuan Berhitung Anak Melalui Permainan Meja Putar Di Taman Kanak-Kanak Subjek penelitian adalah anak didik diKelas B Taman Kanak-kanak Pelita Bunda Batang Lapu Pasaman Barat, dengan jumlah anak sebanyak 15 orang yang terdiri dari 6 laki-laki dan 9 perempuan dilaksanakan dalam dua siklus sebanyak 3 kali pertemuan. Jenis Penelitian yang digunakan pada penelitian ini adalah metode Penelitian Tindakan Kelas (PTK). Tujuan yang akan dicapai dari penelitian ini adalah meningkatkan kemampuan berhitung anak usia dini melalui permainan meja putar di Taman Kanak-kanak Pelita Bunda Batang Lapu Pasaman Barat. Hasil yang di dapat kemampuan berhitung anak melalui permainan meja putar pada kategori BSB (Berkembang Sangat Baik). Aspek anak mampu menyebutkan bilangan 1-10 melalui permainan meja putar, pada siklus I dengan persentase sebesar $20 \%$ dan mengalami kenaikan menjadi $93 \%$ pada siklus II. Dengan demikian disimpulkan bahwa permainan meja putar dengan berbagai media dapat meningkatkan kemampuan berhitung pada anak di Taman Kanak-kanak Pelita Bunda Batang Lapu Pasaman Barat. 
Dari penelitian terdahulu diatas, ada beberapa penelitian yang relevan dengan penulis yaitu penelitian yang dilakukan oleh Nova Oktriyani ( 2017) dengan judul penelitian peningkatan kemampuan berhitung anak usia dini melalui permainan lingkaran angka di taman kanak-kanak Qatrinnada Kecamatan Koto Tangah Padang. Selanjutya Nia Fatmawati (2014) juga melakukan penelitian dengan judul penelitian peningkatan kemampuan berhitung melalui pendekatan realistic mathematic education. Hal yan sama juga di lakuka oleh Rosa Imani Khan dan Ninik Yuliani (2016) dengan judul penelitian, Meningkatkan Kemampuan Berhitung Anak Usia Dini Melalui Permainan Bowling Kaleng. Namun terdapat perbedaan antara penulis dengan penelitian sebelumnya dimana penelitian sebelumnya lebih fokus pada keberhasilan dari tindakan yang diberikan. Sedangkan penulis lebih fokus untuk mengkaji tentang penerapan permainan boling berbahan bekas pada kemampuan berhitung permulaan.

Melalui metode kajian literatur dapat disimpulkan bahwa kagiatan pembelajaran melalui permainan bowling berbahan bekas terbukti dapat meningkatkan kemampuan berhitung permulaan. Kaitan permainan boling berbahan bekas dalam meningkatkan kemampuan berhiung permulaan pada anak terletak pada anak dapat menghitung pin-pin yang terjatuh dan anak dapat menyebutkan angka yang ada di pin tersebut. Pembelajaran melalui kegiatan bermain boling berbahan bekas dapat di kemas dengan cara yang sederhana dan menyenangkan, karena anak belajar sambil bermain sehingga anak tidak merasa bosan.

\section{Kesimpulan}

Secara umum, dari hasil penilitian dapat di simpulkan bahwa penerapan permainan bowling berbahan bekas dapat meningkatkan kemampun berhitung permulaan pada anak. Permainan bowling berbahan bekas dapat memotivasi anak untuk lebih mengenal serta memahami angka atau bilangan 1-10 sehingga berpengaruh terhadap kemampuan berhitung permulaan pada anak. Selain itu permainan bowling berbahan bekas juga dapat mengembangkan aspek perkembangan lainnya pada diri anak seperti perkembangan fisik motorik, dan minat belajar anak.

\section{DAFTAR PUSTAKA}

Anggani, Sudono (2003). Bermain Sebagai sarana Utama Dalam Perkembangan dan Belajar Anak (Anak Usia Dini). Jakarta: Gramedia

Depdiknas.(2008). Kamus Besar Bahasa Indonesia Pusat Bahasa Edisi Keempat. Jakarta: Gramedia Pustaka.

Hurlock (2005). Perkembangan Anak. Jakarta: Erlangga

Himmatul Farihah,2017. Mengembangkan Kemampuan Berhitung Anak Usia Dni Melalui Kegiatan Bermain Stick Angka. Jurnal Teladan, Volume 2 No.1,Mei 2017.

Isnaini Rodhiyah. (2014). Efektivitas Penggunaan Media Permainan Bowling Dalam Materi Operasi Pengurangan Bilangan Pada Anak Tunagrahita Kategori Sedang. Skripsi. PLB FIP UNY.

Khadijah, 2016. Pengembangan Kognitif Anak Usia Dini. Medan: Perdana Mulya Sarana. 
Montolalu, B.E.F.dkk. 2005. Bermain Dan Permainan Anak. Jakarta: Universitas Terbuka.

Nova Oktriyani, 2017. Peningkatan Kemampuan Berhitung Anak Usia Dini Melalui Permainan Lingkaran Angka Di Taman Kanak-Kanak Qatrinnada Kecamatan Koto Tangah Padang. Jurnal Pendidikan Anak Usia Dini. Volume 1. No 1 Oktober 2017.

Nia Fatmawati, 2014. Peningkatan Kemampuan Berhitung Melalui Pendekatan Realistik Mathematich Education. Jurnal Pendidikan Usia Dini. Volume 8 Edisi 2, November 2014.

Putri, L. (2014). Upaya meningkatkan kemampuan berhitung permulaan menggunakan strategi bermain stick angka di Paud. Belia jurnal: Jurnal Ilmiah PG-PA UD IKIP Veteran Semarang, 2 (2), hlm. 3.

Purnomo, Sunyo Adji dan Ranni Novianty. 2013.Games For Fun Learning And Teaching.Bandung : Yrama Widya

Qoyumil Hikmah, Misno A. Lathif, Khutobah, 2016. Peningkatan Kemampuan Berhitung Pada Anak Kelompok B Melalui Permainan Kartu Angka di TK Dharma Indria I Kecamatan Patrang Kabupaten Jembe r. JURNAL EDUKASI UNEJ 2016, III (2): 39-42

Riska Dwi Nurul Hikmah,2017. Penerapan Permaina Bowling Dala Meningkatkan Kemampuan Motorik Kasar Anak Usia Dini Di Raudhatul Athfal Nahdatul Ulma Mataram Baru. Lampung : Skripsi, Fakultas Tarbiyah dan Keguruan

Rosa Imani Khan, 2016. Meningkatkan Kemampuan Berhitung Anak Usia Dini Melalui Permainan Bowling Kaleng. Journal. Volume 10. No.1 Januari 2016.

Sriningsih. 2008. Pembelajaran Matematika Terpadu Untuk Anak Usia Dini. Jakarta: Pustaka Dalaprasta.

Semiawan, Conny. 2008. Belajar dan Pembelajaran Prasekolah dan Sekolah Dasar. Jakarta : Indeks.

Susanto, Ahmad. (2011). Perkembangan anak usia dini. Jakarta: Kencana.

Sri Handayani, 2012. Peningkatan Kemampuan Berhitung Anak Melalui Permainan Ular Tangga Di Taman Kanak-Kanak Aisyiyah Simpang Iv Agam. Jurnal Pesona PAUD Vol.1.No.1

Titin Nirawati, Rivda Yetti, 2019. Peningkatan Kemampuan Berhitung Anak Melalui Permainan Meja Putar Di Taman Kanak-Kanak. JRTI (Jurnal Riset Tindakan Indonesia) Vol. 4 No. 1, hlm. 51-28

Zeed Mestika, 2014. Metode Penelitian Kepustakan, Jakatra: Yayasan Pustaka Obor 